Heilman, F. R. (1948). Proc. Mayo Clin. 23, 569.

Huhtanen, C. N., Rogers, M. R. \& Gall, L. S. (1952). \%. Bact. 64, I7.

Kiser, J. S. (1952). Personal communication.

Miescher, G. \& Böhm, G. (1948). Schweiz. med. Wschr. 77, 82 1.

Murray, E. G. D. (1953). Trans. roy. Soc. Can. 3rd ser., 47, 15.

Perry, T. L. (1949). Proc. Soc. exp. Biol., N.Y., 72, 45.

Ponzoni, R., Giberti, A. \& Spampinato, V. (1953). Boll. Ist, sieroter. Milano, 32, 239 (quoted in Nutr. Abstr. Rev. (1954), 24, 75).

Renoux, G. (1951). Ann. Inst. Pasteur, 81, 54I.

Roine, P., Booth, A. N., Elvehjem, C. A. \& Hart, E. B. (1949). Proc. Soc. exp. Biol., N. Y., 71, 90.

Roine, P. \& Ettala, T. (1952). Nature, Lond, 169, 1014.

Roine, P., Ettala, T. \& Raitio, A. (1953). Acta chem. fenn. B, 26, 17.

Roine, P., Raitio, A. \& Vartiovaara, U. (1953). Nature, Lond,, 172, 767.

Rolle, M. \& Mayer, H. (1953). Arch. Hyg., Berl., 137, 596.

Stenberg, H. (1953). Finsk VetTidskr. 59, 394.

Stuart, P. \& Slavin, G. (1951). Nature, Lond., 167, 319.

Topley, W. W. C. \& Wilson, G. S. (1936). The Principles of Bacteriology and Immunity, and ed. London: E. Arnold and Co.

Westermarck, H. (1946). Finsk VetTidskr. 52, 227.

\title{
Antibiotics and Endocrine Stimulants as Promoters of Growth in Fattening Pigs
}

\author{
By R. BRAUDE* \\ National Institute for Research in Dairying, University of Reading \\ R. C. CAMPBELL† \\ Agricultural Research Council's Unit of Reproductive Physiology \\ and Biochemistry, University of Cambridge \\ I. A. M. LUCAS \\ Rowett Research Institute, Bucksburn, Aberdeenshire \\ J. R. LUSCOMBE \\ Harper Adams Agricultural College, Newport, Shropshire \\ K. L. ROBINSON \\ The Queen's University of Belfast \\ AND J. H. TAYLOR \\ Agricultural Research Council's Field Station, Compton
}

(Received 25 November 1954

Barber, Braude \& Mitchell (I953) reported that the growth-promoting effect associated with the feeding of an antibiotic to pigs was enhanced when it was fed together with small amounts of L-thyroxine and stilboestrol. In order to investigate these findings further, experiments were arranged at the following four centres: the 
Agricultural Research Council's Field Station, Compton; the Rowett Research Institute, Bucksburn; the Harper Adams Agricultural College, Newport; and the Research Institute of Northern Ireland, Hillsborough. After the experiments at Compton and the Rowett had begun Barber et al. (r954) produced at the National Institute for Research in Dairying, Shinfield, near Reading, preliminary evidence suggesting that stilboestrol could be omitted from the supplement without markedly impairing the effectiveness of the combination. Furthermore, as some adverse effects, due apparently to the use of stilboestrol, were encountered at both Compton and the Rowett, the original uniform plan of the experiment was altered to include a comparison of treatments with an antibiotic and $\mathrm{L}$-thyroxine, and with an antibiotic and L-thyroxine and stilboestrol. (For brevity, the five centres will be referred to as Compton, Rowett, Harper Adams, Hillsborough and Shinfield.)

\section{METHODS}

Experimental procedure. Table $\mathrm{r}$ gives the experimental treatments used at the five centres.

Table I. Treatments (indicated by $x$ ) used for the pigs at the five centres

\begin{tabular}{|c|c|c|c|c|c|c|c|c|c|c|}
\hline \multirow[b]{2}{*}{ Centre* } & \multirow[b]{2}{*}{$\begin{array}{l}\text { No. of } \\
\text { pigs in } \\
\text { each } \\
\text { group }\end{array}$} & \multicolumn{9}{|c|}{ Experimental treatments } \\
\hline & & $\begin{array}{l}\text { Control } \\
\text { (C) }\end{array}$ & $\begin{array}{c}\text { Thyroxine } \\
\text { (T) }\end{array}$ & $\begin{array}{c}\text { Thyroxine } \\
\text { + stilb- } \\
\text { oestrol } \\
\text { (TS) }\end{array}$ & $\begin{array}{l}\text { Aureo- } \\
\text { mycin } \\
\text { (A) }\end{array}$ & $\begin{array}{l}\text { Peni- } \\
\text { cillin } \\
\text { (P) }\end{array}$ & $\begin{array}{c}\text { Thyroxine }+ \\
\text { aureomycin } \\
\text { (TA) }\end{array}$ & $\begin{array}{c}\text { Thyroxine } \\
+ \\
\text { penicillin } \\
\text { (TP) }\end{array}$ & $\begin{array}{l}\text { Thyroxine+ } \\
\text { stilboestrol }+ \\
\text { aureomycin } \\
\text { (TSA) }\end{array}$ & $\begin{array}{l}\text { Thyroxine+ } \\
\text { stilboestrol }+ \\
\text { penicillin } \\
\text { (TSP) }\end{array}$ \\
\hline Compton & 6 & $x$ & - & $x$ & $x$ & $x$ & - & - & $x$ & $x$ \\
\hline Rowett & 5 & $x$ & $\ldots$ & $x$ & $x+$ & $x$ & - & - & $x$ & $x$ \\
\hline Shinfield & 9 & $x t$ & $x$ & - & $x$ & $x+$ & $x$ & $x+$ & - & - \\
\hline Harper Adams & is 5 & $x$ & - & - & $x$ & - & $x$ & - & $x$ & - \\
\hline Hillsborough & 6 & $x$ & - & - & $x$ & -- & $x$ & - & $x$ & - \\
\hline $\begin{array}{r}\text { C: for com } \\
\text { T: thyroxin } \\
\text { diet. } \\
\text { TS: as unde } \\
\text { A: aureom } \\
\text { aureo } \\
\text { P: penicilli } \\
\text { TA: treatme } \\
\text { TP: treatme } \\
\text { TSA: treatme } \\
\text { TSP: treatme } \\
\text { * The pigs } \\
\text { T Results f }\end{array}$ & $\begin{array}{l}\text { npositior } \\
\text { ine was i } \\
\text { let } \mathrm{T} \text {, bu } \\
\text { ycin in } \\
\text { omycin } \\
\text { lin in th } \\
\text { ents T a } \\
\text { ents T a } \\
\text { ents TS } \\
\text { ents TS } \\
\text { were fe }\end{array}$ & $\begin{array}{l}\text { n of the } \\
\text { ncluded } \\
\text { ut with } d \\
\text { the form } \\
\text { ton. } \\
\text { le form of } \\
\text { ind } A \text { con } \\
\text { ind } P \text { com } \\
\text { and } A \text { co } \\
\text { and } P \text { co }\end{array}$ & $\begin{array}{l}\text { control diets } \\
\text { as sodium L- } \\
\text { liethylstilboe } \\
\text { n of Aurofa } \\
\text { f procaine pe } \\
\text { mbined. } \\
\text { nbined. } \\
\text { ombined. } \\
\text { ombined. }\end{array}$ & $\begin{array}{l}\text { see Table } \\
\text { thyroxine } p \\
\text { strol added } \\
\text { c } 2 \text { A (Lede } \\
\text { enicillin wa }\end{array}$ & $\begin{array}{l}2 . \\
\text { at the } r \\
\text { erle Lab } \\
\text { is mixed }\end{array}$ & $\begin{array}{l}\text { te (Gla } \\
\text { te of } 6 \\
\text { ratories } \\
n \text { the } r 8\end{array}$ & $\begin{array}{l}\text { xo Laboratori } \\
\text { Ing/lb. diet. } \\
\text { Inc.) was mi } \\
\text { tion at the rat }\end{array}$ & $\begin{array}{l}\text { ies Ltd), sup } \\
\text { iixed in the } \\
\text { te of } 18 \mathrm{~g} / \mathrm{to}\end{array}$ & $\begin{array}{l}\text { plying } 0.3 \\
\text { ration at } \\
\text { on. }\end{array}$ & $\begin{array}{l}\text { thyroxine } / \mathrm{lb} \text {. } \\
\text { rate of } \mathrm{r} 8 \mathrm{~g}\end{array}$ \\
\hline
\end{tabular}

The routine adopted was the same, except for small details, at all centres. Only castrated male pigs were used except at Shinfield where, as stilboestrol was not employed, pigs of both sexes were included. Each experimental unit consisted of litter-mates, one pig from a unit being allocated to each treatment; all the pigs receiving the same treatment were housed together in one pen. The initial weights of the pigs within each experimental unit were similar, but there was considerable variation between the initial weights of pigs in different units and also between centres (cf. Table 3). Individual feeding was practised at all centres except Compton, where group feeding was employed. The pigs were fed twice daily. The food allowance 
was based on a $10 \%$ increase in the live-weight scale for fattening pigs used by Braude \& Mitchell (1950-I), except at Compton where the pigs were fed to appetite, though their maximum intake did not exceed that of the scale used in the other centres. The dry meals were mixed with water immediately before feeding, $3 \mathrm{lb}$. water being added to each lb. meal. Each centre used its normal ration for fattening pigs except for the experimental supplements, which were standardized. Details of the diets are given in Table 2. The experimental period lasted until the pigs reached about $210 \mathrm{lb}$. live weight, except at Shinfield where it was limited to 17 weeks, when the pigs were sold for slaughter.

Table 2. Percentage compositions of the diets given to the pigs

\begin{tabular}{|c|c|c|c|c|c|c|c|}
\hline \multirow[b]{2}{*}{ Ingredient } & \multicolumn{2}{|c|}{ Compton } & \multicolumn{2}{|c|}{ Rowett } & \multirow[b]{2}{*}{ Shinfield } & \multirow[b]{2}{*}{$\begin{array}{l}\text { Harper } \\
\text { Adams }\end{array}$} & \multirow[b]{2}{*}{$\begin{array}{l}\text { Hills- } \\
\text { borough }\end{array}$} \\
\hline & $\begin{array}{c}\text { Up to } \\
20 \text { weeks } \\
\text { of age }\end{array}$ & $\begin{array}{l}\text { Over } \\
20 \text { weeks } \\
\text { of age }\end{array}$ & $\begin{array}{l}\text { Up to } \\
\text { roolb. live } \\
\text { weight }\end{array}$ & $\begin{array}{l}\text { roo-20olb. } \\
\text { live } \\
\text { weight }\end{array}$ & & & \\
\hline Barley meal & 40 & 55 & 43 & 47 & 30 & 30 & 37 \\
\hline Wheat offals & 40 & 20 & Io & 12 & 50 & 50 & 25 \\
\hline Flaked maize & Io & Io & I 5 & 15 & 10 & ro & $20^{*}$ \\
\hline Fish meal & $7 \cdot 5$ & - & 7 & 2 & 10 & 10 & 10 \\
\hline Grass meal & $2 \cdot 5$ & 5 & 5 & 3 & - & - & 3 \\
\hline Ground oats & -3 & ro & 15 & 15 & - & - & - \\
\hline $\begin{array}{l}\text { Extracted decorticated } \\
\text { groundnut meal }\end{array}$ & - & - & 4 & 4 & - & 一 & 5 \\
\hline Minerals & $\dagger$ & + & If & $2 \S$ & $\|$ & - & $\|$ \\
\hline $\begin{array}{l}\text { * Maize meal. } \\
\uparrow \text { Plus } 44 \mathrm{lb} \text {./ton of } \mathrm{m} \\
\text { part salt. } \\
\text { I Composed of } 103 \mathrm{pa} \\
\text { berdeen) (containing ro } \\
\$ \text { Composed of } 66.5 \mathrm{pa} \\
3.5 \text { parts Adisco. } \\
\text { II A small amount of c }\end{array}$ & $\begin{array}{l}\text { ninerals c } \\
\text { arts grour } \\
\text { ooo i.u. v } \\
\text { arts grour }\end{array}$ & $\begin{array}{l}\text { consisting } \\
\text { nd limesto } \\
\text { itamin A a } \\
\text { nd limesto }\end{array}$ & $\begin{array}{l}\text { of } 3 \text { parts } \\
\text { one, } 103 \text { par } \\
\text { and } 200 \text { i.u. } \\
\text { one, } 190 \text { part }\end{array}$ & $\begin{array}{l}\text { ground chal } \\
\text { rts salt, } 227 \\
\text { vitamin } \mathrm{D} / \mathrm{g} \\
\text { ts sterilised }\end{array}$ & $\begin{array}{l}\text { parts Adi } \\
\text { g). } \\
\text { steamed }\end{array}$ & $\begin{array}{l}\text { med b } \\
\text { Isaac } S \\
\text { flour, }\end{array}$ & $\begin{array}{l}\text { cer \& } \\
\text { parts }\end{array}$ \\
\hline
\end{tabular}

Biometrical methods. The variations in the number of days in the fattening period and in the food consumed, caused by differences between pigs in initial and final weights, were allowed for by interpolation on the growth curves (for final weight) and by regression analyses (for initial weight). The independent variable in these regression analyses was the initial weight, separate analyses being carried out for each treatment at each centre; the regression coefficients obtained in these analyses were averaged over treatments within centres and the pooled coefficients were used to correct the number of days and the food consumption to a constant initial starting weight. Missing values, caused by the death or removal of some pigs, were estimated by minimizing the within-pen variance. The corrected and completed values for the number of days and for the food consumed were analysed centre by centre in suitable analyses of variance.

The effects of the treatments with aureomycin and with L-thyroxine and aureomycin were compared from the results obtained at Shinfield, Harper Adams and Hillsborough, and the treatments with aureomycin and with L-thyroxine and stilboestrol and aureomycin were studied in the results for Compton, Rowett, Harper Adams and 
Hillsborough. In these analyses the interactions between the centre and the treatment were compared with the within-centre residuals, and as in both analyses the interactions were significantly large they, rather than the residuals, were used to test the effects of treatment.

\section{RESULTS}

The results obtained at each centre, together with the relevant details of the statistical analysis, are given in Tables 3 and 4 . These tables also contain pooled results for treatments carried out at several centres.

Table 3. Mean daily live-weight gain (lb.) of the pigs at the different centres and on the different treatments

\begin{tabular}{|c|c|c|c|c|c|c|c|c|c|c|c|c|}
\hline \multirow[b]{2}{*}{ Centre } & \multirow{2}{*}{$\begin{array}{c}\text { Initial } \\
\text { weight } \\
\text { (lb.) }\end{array}$} & \multicolumn{9}{|c|}{ Treatment* } & \multirow{2}{*}{$\begin{array}{c}\text { z test, } \\
\text { level } \\
\text { of sig- } \\
\text { nificance } \\
(\%)\end{array}$} & \multirow{2}{*}{$\begin{array}{c}\text { Standard } \\
\text { error of } \\
\text { each } \\
\text { treat- } \\
\text { ment } \\
\text { mean }\end{array}$} \\
\hline & & C & $\mathbf{T}$ & TS & A & $\mathbf{P}$ & r TA & $\mathrm{TP}$ & TSA & TSP & & \\
\hline I, Compton & $49^{\cdot 6}$ & $1+53$ & - & $I \cdot 53$ & $I \cdot 68$ & $I \cdot 62$ & - & - & $I \cdot 51$ & $I \cdot 63$ & $>20$ & 0.071 \\
\hline 2, Rowett & $33 \cdot 5$ & $1 \cdot 13$ & - & $1 \cdot 18$ & I'30 & $1 \cdot 28$ & - & - & $I \cdot 26$ & $1 \cdot 28$ & o. I & 0.022 \\
\hline 3, Shinfield & $45^{\circ} 4$ & $I \cdot 19$ & $I \cdot 25$ & - & $x \cdot 35$ & $1 \cdot 32$ & $1 \cdot 44$ & I'37 & - & - & $1 \cdot 0$ & 0.042 \\
\hline 4, Harper Adams & $56 \cdot 1$ & $I \cdot I 4$ & $\longrightarrow$ & 一 & $I * 12$ & - & $I \cdot I O$ & $-\infty$ & $I \cdot 25$ & - & $>20$ & 0.050 \\
\hline 5, Hillsborough & $39^{\circ} 8$ & $I * 40$ & 一 & - & $1 \cdot 41$ & - & $1 \cdot 48$ & - & $1 \cdot 57$ & - & $0 \cdot 1$ & 0.021 \\
\hline $3+4+5$ & - & $I \cdot 24$ & 一 & - & $1 \cdot 29$ & $\rightarrow$ & $1 \cdot 34$ & - & - & - & 20 & 0.039 \\
\hline$I+2+4+5$ & - & $I \cdot 29$ & $一$ & - & I'37 & - & - & - & $I \cdot 40$ & - & $>20$ & 0.040 \\
\hline
\end{tabular}

The effects of variations within centres in initial and final weights have been removed as described in the text, p. I93. The $z$ test (Fisher, 1950) refers to the overall comparison between the treatment means. 'The standard errors for the individual centres were estimated from the within-treatment variation, but those for the pooled analyses were obtained from the centre $x$ treatment interaction.

* See Table I.

Table 4. Mean efficiency of food utilization (lb./lb. live-weight gain) of the pigs at the different centres and on the different treatments

\begin{tabular}{|c|c|c|c|c|c|c|c|c|c|c|c|c|}
\hline \multirow[b]{2}{*}{ Centre } & \multirow{2}{*}{$\begin{array}{c}\text { Initial } \\
\text { weight } \\
\text { (lb.) }\end{array}$} & \multicolumn{9}{|c|}{ Treatment* } & \multirow{2}{*}{$\begin{array}{c}z \text { test, } \\
\text { level } \\
\text { of sig- } \\
\text { nificance } \\
(\%)\end{array}$} & \multirow{2}{*}{$\begin{array}{c}\text { Standard } \\
\text { error of } \\
\text { each } \\
\text { treat- } \\
\text { ment } \\
\text { mean }\end{array}$} \\
\hline & & C & $\mathrm{T}$ & $\mathrm{TS}$ & A & $\mathbf{P}$ & TA & $\mathbf{T P}$ & TSA & $\overrightarrow{\text { TSP }}$ & & \\
\hline I, Compton & $49 \cdot 6$ & $3 \cdot 06$ & - & 3.08 & $2 \cdot 85$ & $2 \cdot 97$ & - & - & $3 \cdot 10$ & 3.01 & - & - \\
\hline 2, Rowett & $33 \cdot 5$ & $3 \cdot 77$ & 一 & $3 \cdot 58$ & $3 \cdot 37$ & 346 & - & - & 354 & 3.35 & 0.1 & 0.061 \\
\hline 3, Shinfield & $45^{\circ} 4$ & $3 \cdot 66$ & 3.57 & - & $3 \cdot 60$ & $3 \cdot 56$ & 3.57 & 3.55 & - & - & Io & 0.025 \\
\hline 4, Harper Adams & $5^{6 \cdot 1}$ & 3.73 & - & - & $3 \cdot 73$ & - & $3 \cdot 93$ & - & 3.43 & - & $I \cdot 0$ & 0.075 \\
\hline 5, Hillsborough & $39 \cdot 8$ & $3 \cdot 26$ & - & - & $3 \cdot 33$ & - & $3 \cdot 19$ & - & $2 \cdot 94$ & - & 0.1 & 0.054 \\
\hline $3+4+5$ & - & 3.55 & 一 & - & $3 \cdot 55$ & - & 3.54 & - & - & - & $>\mathbf{2 0}$ & 0.044 \\
\hline $1+2+4+5$ & - & $3 \cdot 43$ & 一 & - & $3 \cdot 3^{\circ}$ & - & - & - & $3 \cdot 23$ & - & $>20$ & 0.090 \\
\hline
\end{tabular}

The effects of variations within centres in initial and final weights have been removed as described in the text, $p$. 193. The $z$ test (Fisher, 1950) refers to the overall comparison between the treatment means. No significance tests were possible on the Compton results because individual feeding was not used. The standard errors for the individual centres were estimated from the within-treatment variation, but those for the pooled analyses were obtained from the centre $x$ treatment interaction. * See Table $x$.

At Compton and Rowett, which used the same treatments, there was a stimulation of growth due to the inclusion of antibiotics in the diet. The stimulation obtained at Compton was, however, not significant. The efficiency of food utilization was significantly improved at the Rowett, but statistical analysis of the Compton results was not possible because group feeding was employed there. In both centres the combination of antibiotics and L-thyroxine and stilboestrol produced no significant effect 
above that recorded for antibiotics alone. The L-thyroxine plus stilboestrol treatment gave no response whatever at Compton, but a slight improvement in both growth rate and the efficiency of food conversion was recorded at Rowett.

The results from Harper Adams and Hillsborough, where only three of the treatments used at Compton and Rowett were replicated, were not the same as those just described. At Harper Adams and Hillsborough there was no stimulation of growth due to feeding an antibiotic, but there was a significant improvement when L-thyroxine and stilboestrol were fed together with the antibiotic. A significant stimulation with L-thyroxine plus antibiotic (without stilboestrol) was recorded at Hillsborough but not at Harper Adams. The results for the efficiency of food utilization were very similar to those for the rate of growth.

At Shinfield the rate of growth was significantly increased by the feeding of antibiotics, and by the addition of L-thyroxine to the diet; these two effects appeared to be additive. The overall test for treatment differences in the efficiency of food utilization gave a non-significant result, but it appeared that all treatments gave somewhat better results than the control.

In the between-centre analyses described above, in which the effects of some of the treatments at several centres were compared, although interactions between treatments were significant, the pooled treatment differences were not.

At Compton in the and week of the experiment, five pigs receiving the treatment with L-thyroxine and stilboestrol became ill, and within a short time three of them died. The signs encountered have been described fully by Taylor \& Gordon (1955), who, after some additional investigation, attributed them to stilboestrol poisoning. At Rowett, two animals appeared to be similarly affected, but after a few days of isolation they recovered. No similar cases were observed at Harper Adams, Hillsborough, or in the previous experiments in which stilboestrol was used at Shinfield.

\section{DISCUSSION}

The main difficulty in the interpretation of these results is the marked variation in response to a given treatment at the different centres. No doubt this variation was to some extent due to the use of animals of different origin and of diets of different composition. The prevalence of virus pneumonia in most of the centres may also have had some adverse effect on the uniformity of the results.

Although in two out of the four centres the results of Barber et al. (1953), pointing to the possibility of enhancing the growth-promoting effect of antibiotics by feeding them together with L-thyroxine and stilboestrol, were confirmed, we do not think that such a treatment merits further consideration because of the possibility of stilboestrol poisoning (Taylor \& Gordon, 1955). The toxicity of stilboestrol needs further investigation.

When stilboestrol is left out of the combination, it appears that under the conditions of two out of three centres a significant improvement in the rate of growth may be obtained by adding L-thyroxine to diets containing an antibiotic, over and above the improvement obtained with the antibiotic alone. Further experimental work is needed to confirm this result under practical conditions. 
I. A co-ordinated experiment involving 154 pigs in five centres was carried out in order to establish whether the growth-promoting effect associated with the feeding of an antibiotic with a normal fattening diet was enhanced when the antibiotic was supplemented with L-thyroxine alone or with stilboestrol.

2. Marked variation in response to a given treatment was recorded at the different centres. In one of the centres toxic signs were observed, apparently associated with the feeding of stilboestrol, and the advisability of using the substance for promoting growth is thus open to doubt. In two out of three centres a significant growth response was obtained by adding L-thyroxine to diets containing an antibiotic.

We are indebted to Glaxo Laboratories Ltd for the gift of L-thyroxine and to Lederle Laboratories Inc. for the gift of Aurofac $2 \mathrm{~A}$.

\section{REFERENCES}

Barber, R. S., Braude, R. \& Mitchell, K. G. (1953). Chem. \& Ind. p. 410.

Barber, R. S., Braude, R. \& Mitchell, K. G. (1954). Chem. E' Ind. p. 76.

Braude, R. \& Mitchell, K. G. (1950-1). F. Minist. Agric. 57, 50r.

Fisher, R. A. (1950). Statistical Methods for Research Workers, 1 t th ed. Edinburgh: Oliver and Boyd.

Taylor, J. H. \& Gordon, W. S. (1955). Vet. Rec. 67, 48. 